\title{
A complete passerine foot from the late Oligocene of Poland
}

\author{
Zbigniew M. Bochenski, Teresa Tomek, and Ewa Swidnicka
}

\begin{abstract}
The paper describes a nearly complete articulated specimen of a passerine foot imprinted on a slab and counter slab of the siliceous clayey shales belonging to the upper part of the Menilite Formation of the Outer Carpathians in southeastern Poland and dated to the late Oligocene (Chattian, ca. 25 m.y.a.). It is one of the very few Paleogene specimens of passerines and just the third with a complete foot preserved. Its passerine affinities were established on the basis of a combination of characteristic features but owing to the incompleteness of the specimen its more precise systematic position within Passeriformes cannot be resolved. For the same reason the specimen is not described as a new extinct species although it differs from all known Oligocene passerines. The proportions of phalanges, size of the tarsometatarsus and shape of claws point to an arboreal bird, which increases the known Paleogene diversity of this bird group.
\end{abstract}

Zbigniew M. Bochenski. Institute of Systematics and Evolution of Animals, Polish Academy of Sciences, Slawkowska 17, 31-016 Krakow, Poland, bochenski@isez.pan.krakow.pl

Teresa Tomek. Institute of Systematics and Evolution of Animals, Polish Academy of Sciences, Slawkowska 17, 31-016 Krakow, Poland, tomek@isez.pan.krakow.pl

Ewa Swidnicka. Department of Palaeozoology, Chair of Evolutionary Biology and Ecology, University of Wrocław, Sienkiewicza 21, 50-335 Wrocław, Poland, gama@biol.uni.wroc.pl

Keywords: Fossil birds; Passeriformes; Menilite shales; Carpathian flysch; Oligocene; Paleogene

\section{INTRODUCTION}

The order Passeriformes includes more than half of all extant bird species but little is known about its early history because of the paucity of its fossil record from the Paleogene. The oldest two fossils of possible passerine affinities were found in Australia and are dated to the early Eocene (Boles,
$1995,1997)$, but unquestionable remains of passeriforms come from the Oligocene of Europe. So far only three species based on relatively complete specimens have been described from the Oligocene: Wieslochia weissi Mayr and Manegold, 2006 from Germany (Mayr and Manegold, 2004, 2006a) and two species from Poland - Jamna szybiaki Bochenski, Tomek, Bujoczek, and Wertz, 2011

PE Article Number: 17.1.6A

Copyright: Palaeontological Association February 2014

Submission: 17 September 2013. Acceptance: 27 January 2014

Bochenski, Zbigniew M., Tomek, Teresa, and Swidnicka, Ewa. 2014. A complete passerine foot from the late Oligocene of Poland. Palaeontologia Electronica Vol. 17, Issue 1;6A; 7p; palaeo-electronica.org/content/2014/674-oligocene-passerine-foot 


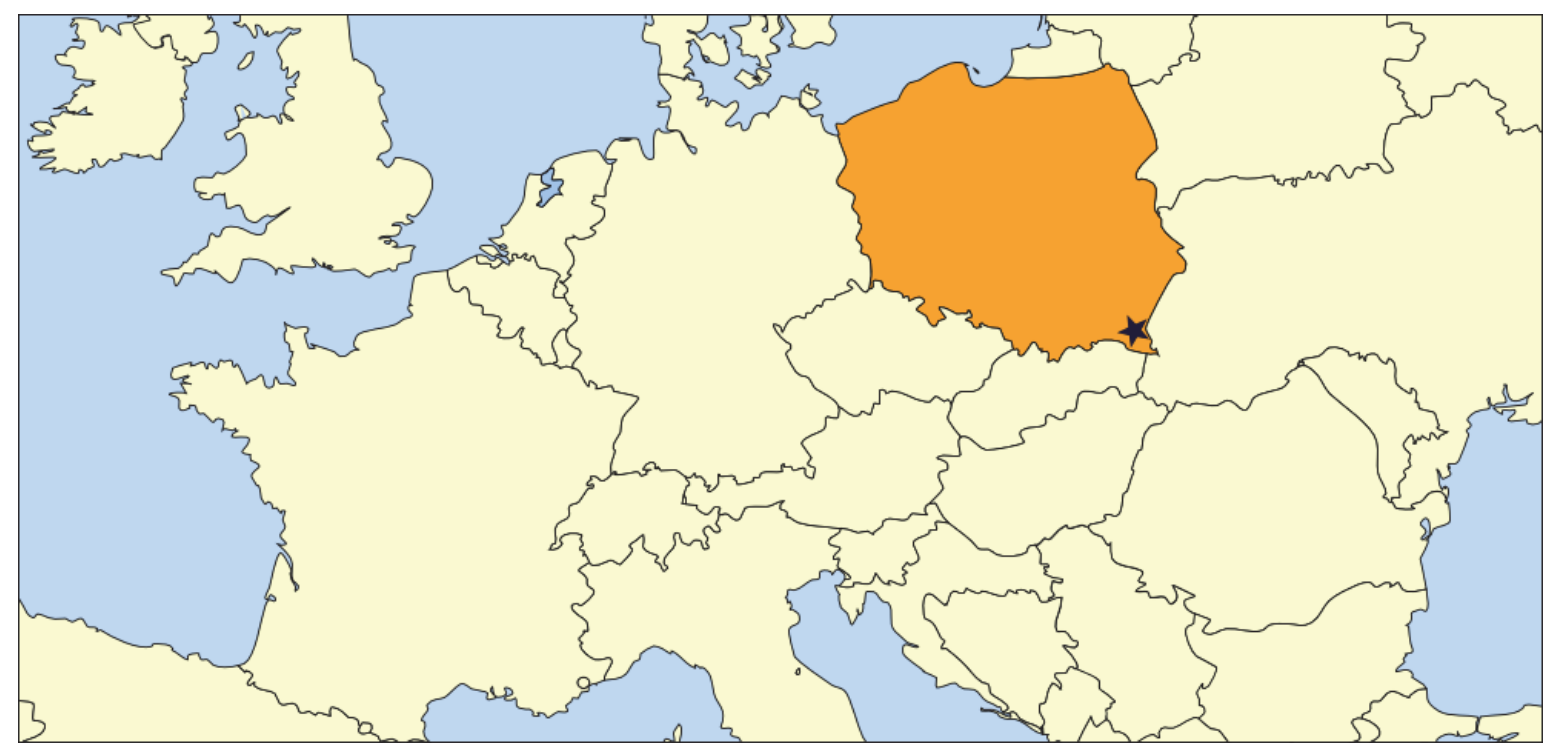

FIGURE 1. A map of Europe with Poland (orange) and the location of the village of Hłudno (asterisk) in southeastern Poland, where the specimen ZPALWr. A/4005 was found.

(Bochenski et al., 2011) and Resoviaornis jamrozi Bochenski, Tomek, Wertz, and Swidnicka, 2013 (Bochenski et al., 2013a). All three species are dated to the early Oligocene, and their systematic position within Passeriformes remains unresolved because they show a mosaic of characters typical for the Oscines or Suboscines. Another complete specimen of a passerine bird was found in the early Oligocene of Lubéron, France, but it has not been described yet (Mayr, 2009). The remaining Oligocene remains described in the literature include an articulated wing (Mayr and Manegold, 2006b) and a handful of isolated wing bones those from the late Oligocene represent both Oscines and Suboscines (Manegold, 2008; Mourer-Chauviré et al., 1989). Leg bones and especially their distal elements are even rarer. Legs of Wieslochia weissi, Jamna szybiaki and Resoviaornis jamrozi are incomplete. Only one specimen of a complete articulated passerine leg is known from the Oligocene (Bochenski et al., in press). Apart from it, only two other fragments of the tarsometatarsus are known from the Oligocene of France (Mourer-Chauviré, 2006; Mourer-Chauviré et al., 1989, 2004).

In this paper, we describe a nearly complete articulated specimen of a passerine foot found in southeastern Poland (Figure 1) which is a large region, very abundant in fossil remains preserved in marine deposits of the former Paratethys Ocean (Bochenski et al., 2013b). Animal fossils other than fishes are found only sporadically there and birds are also extremely rare. The paper provides new details on the scanty record of the foot morphology of Paleogene passerines and increases the known diversity of this bird group.

\section{METHODS}

Osteological terminology follows Baumel and Witmer (1993). Dimensions are given in millimeters and refer to the greatest length along the longitudinal axis of the bone. The fossil was compared with extant specimens from the osteological collection of the Institute of Systematics and Evolution of Animals, Krakow, Poland. The fossiliferous horizon in the village of Hłudno has been dated on the basis of the fish assemblage and correlated with the calcareous nannoplankton (Berggren et al., 1995; Kotlarczyk et al., 2006).

\section{SYSTEMATIC PALEONTOLOGY}

Class AVES Linnaeus, 1758

Order PASSERIFORMES Linnaeus, 1758

Family, genus, and species indeterminate

Material. Two slabs (Figures 2,3) with imprints of a complete right passerine foot, deposited at the Division of Palaeozoology, University of Wroclaw, Poland (ZPALWr. A/4005). Found in 1976, first mentioned in the literature in 1979 (Bochenski and Szymczyk, 1979).

Locality and horizon. The specimen was found at one of the 15 exposures of Oligocene marine deposits in the Menilite Formation of Skole Nappe of the Outer Carpathians, situated along a forest 

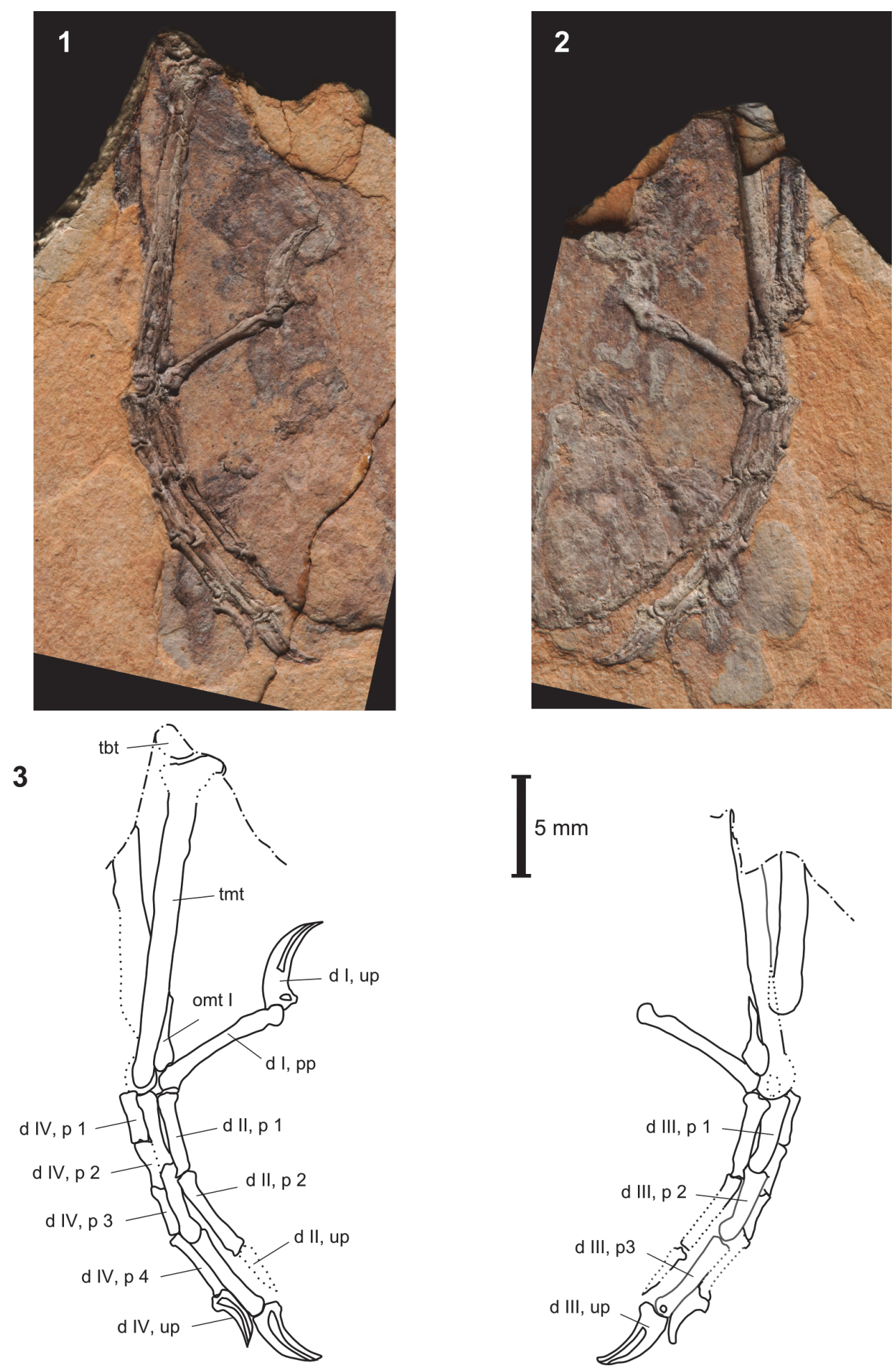

FIGURE 2. Specimen ZPALWr. A/4005 of a passerine bird foot from southeastern Poland, Hłudno, late Oligocene, ca. 25 m.y.a. 1, Main slab; 2, Counter slab; 3, Interpretative drawings of the main slab and counter slab. Abbreviations: $d$ I, pp - digit I, proximal phalanx; d I, up - digit I, ungual phalanx; d II, p1 - digit II, phalanx 1; d II, p2 - digit II, phalanx 2; d II, up - digit II, ungual phalanx; d III, p1 - digit III, phalanx 1; d III, p2 - digit III, phalanx 2; d III, p3 - digit III, phalanx 3; d III, up - digit III, ungual phalanx; d IV, p1 - digit IV, phalanx 1; d IV, p2 - digit IV, phalanx 2; d IV, p3 - digit IV, phalanx 3; d IV, p4 - digit IV, phalanx 4; d IV, up - digit IV, ungual phalanx; omt I - os metatarsale I; tmt - tarsometatarsus; tbt - tibiotarsus (fragment of the condylus lateralis). 

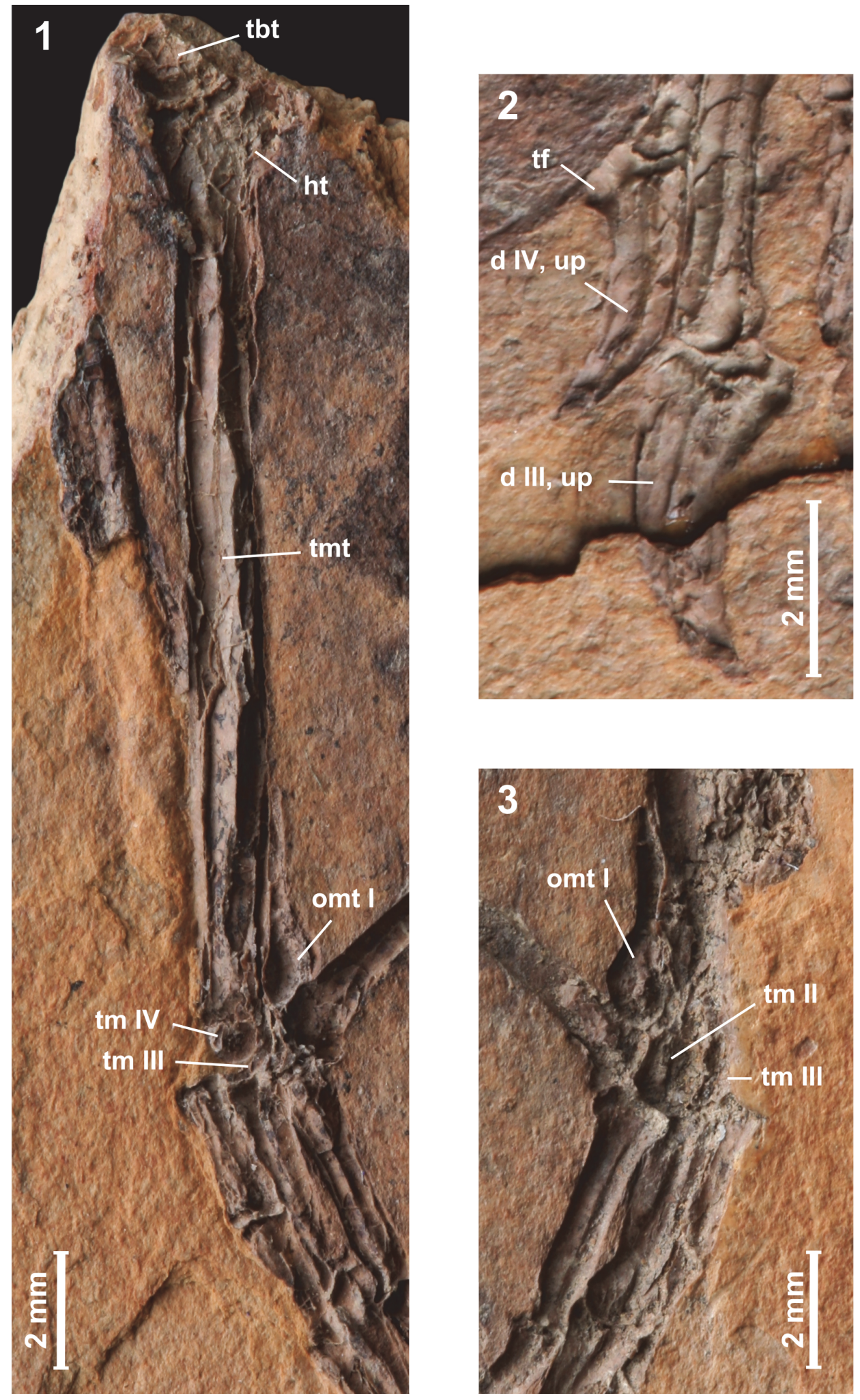

FIGURE 3. Specimen ZPALWr. A/4005 of a passerine bird foot from southeastern Poland, Hłudno, late Oligocene, ca. 25 m.y.a. 1, Enlarged tarsometatarsus from main slab; 2, Enlarged ungual phalanges (claws) of digits III and IV from main slab; 3, Enlarged distal tarsometatarsus from counter slab; Abbreviations: d III, up - digit III, ungual phalanx; ht hypotarsus; omt I - os metatarsale I; tf - tuberculum flexorium; tm II - trochlea metatarsi II; tm III - trochlea metatarsi III; tm IV - trochlea metatarsi IV; tmt - tarsometatarsus; tbt - tibiotarsus (fragment of the condylus lateralis). 
road in the village of Hłudno, about $7 \mathrm{~km}$ southwest of Dynów and $30 \mathrm{~km}$ southeast of Rzeszów, Podkarpackie Voivodeship, southeastern Poland (Figure 1). Geographical coordinates of the site: $49^{\circ} 46.835^{\prime} \mathrm{N}, 022^{\circ} 08.122^{\prime} \mathrm{E}$. ZPALWr. A/4005 was found in association with several articulated fish imprints including Eovinciguerria obscura (Daniltshenko, 1946), Eomyctophum koraense Daniltshenko, 1947, Sardinella sardinites (Heckel, 1850) and Alosa sp., Linck, 1790. The fish taxa composition is characteristic of the upper bathypelagic assemblage of IPM6 zone (Kotlarczyk et al., 2006) which correlates with the calcareous nannoplankton of the upper part of the NP25 zone sensu Berggren et al. (1995) and indicates a late Oligocene age (Chattian, ca. 25 m.y.a.) for the assemblage.

Diagnosis. Small passerine, approximately the size of a Great Tit Parus major or a Tree Sparrow Passer montanus, which is distinguished from all other non-passerine taxa by the combination of the following characters: (1) the tarsometatarsus bears a relatively short proximo-distally hypotarsus, (2) a marked crista plantaris lateralis, and (3) has the small trochleae of the second, third and fourth pedal digits arranged in a line (i.e., dorso-plantarly level in distal aspect) and reaching approximately equally far distally; (4) the specimen shows an anisodactyl foot; (5) the proximal phalanx of the hallux is greatly elongated; (6) on each digit the penultimate phalanx is the longest; (7) the claws show relatively little curvature and their tubercula flexoria are weakly developed.

\section{Description and Comparison}

Similarly to other bird fossils from the Oligocene of Poland (Bochenski and Bochenski, 2008; Bochenski et al., 2010, 2011, in press), particular elements in ZPALWr.A/4005 are broken longitudinally and preserved as imprints partly lined with remnants of bone. Therefore, often a mixture of an imprint and the inner side of a bone rather than its external surface is visible, which sometimes makes it difficult to recognize the left and right sides or the anterior and posterior views at first glance, especially in the photographs.

Measurements (maximum length in $\mathrm{mm}$ ). tarsometatarsus, 18.0; hallux: proximal phalanx, 7.4; hallux: claw, 4.9; first phalanx of digit II, 4.4; second phalanx of digit II, 5.1 ; claw of digit II, $~ 3.1$; first phalanx of digit III, $\sim 4.0$; second phalanx of digit III, 4.2; third phalanx of digit III, 5.4; claw of digit III, 4.1; first phalanx of digit IV, 2.7; second phalanx of digit IV, 2.6; third phalanx of digit IV, 2.7; fourth phalanx of digit IV, 3.8; claw of digit IV, 3.3.
The percent lengths of the nonungual phalanges of digit III are as follows: Phalanx III-1, 29.4\%; Phalanx III-2, 30.9\%; and Phalanx III-3, 39.7\%.

Tibiotarsus. A small fragment of the condylus lateralis is visible on the main slab but it is too poorly preserved to allow meaningful comparisons.

Tarsometatarsus. An imprint of the lateral side with remnants of bone is seen in the main slab, and a partial imprint of the medial side is preserved on the counter slab. The tarsometatarsus is similar in length to that in the early Oligocene Wieslochia weissi and distinctly shorter than in ZPALWr. A/ 4004 from Przysietnica (Bochenski et al., in press); among extant species, its size corresponds to that in Parus major or Passer montanus. As in extant passeriforms, the lateral edge of the cotyla lateralis is slanting somewhat distally toward the dorsal side. The eminentia intercondylaris is not preserved. The exact outline of the hypotarsus is not preserved because fragments of its distal edge are hidden in the matrix. However, it is clear that the hypotarsus is relatively short proximo-distally as in all extant passeriforms and the early Oligocene ZPALWr. A/4004 from Przysietnica (Bochenski et al., in press). No details of hypotarsal canals and/or furrows are visible. The shaft bears a marked crista plantaris lateralis, which is hidden in Figures 2 and 3 under an overhanging edge of matrix but is visible when the main slab is tilted. The marked crista is present only in extant passerines and cuckoos (Manegold et al., 2004) and it was also present in the extinct early Oligocene passerine ZPALWr. A/ 4004 from Przysietnica (Bochenski et al., in press). The distal end with the small trochleae of the second, third and fourth pedal digits that are arranged in a line (i.e., dorso-plantarly level in distal aspect) is highly characteristic for all passeriforms. The well-imprinted trochlea metatarsi IV reaches only a little less distally than the shallower imprinted trochlea metatarsi III (seen in the main slab). Also, the trochlea metatarsi II is only a little shorter than the trochlea metatarsi III (seen in the counter slab). Toes. As in all passeriforms, the foot has anisodactyl arrangement of toes, with three digits directed forward and one digit directed backwards. The phalangeal formula is 2-3-4-5. As in most extant passerines, all digits are thin and relatively long although on each digit the penultimate phalanx is clearly the longest. In the early Oligocene ZPALWr. A/4004 from Przysietnica the second and the third phalanges of digit III were approximately of the same length. As in all other passeriforms, the os metatarsale I bears a cylindrical trochlea metatarsi I. Also as in all extant passeriforms, the early Oligo- 
cene Wieslochia weissi and ZPALWr. A/4004 from Przysietnica (Bochenski et al., in press), the proximal phalanx of the hallux is greatly elongated. The third digit is the longest; its length is approximately the same as that of the tarsometatarsus. The second digit is a little shorter than the fourth. The claws show relatively little curvature, their tubercula flexoria are weakly developed and they bear a groove along their length.

\section{DISCUSSION}

While there is no doubt that ZPALWr. A/4005 belongs in Passeriformes, its more precise affinities remain unresolved due to the incompleteness of the specimen and large number of extant taxa. The fact that ZPALWr. A/4005 differs in absolute size and proportions from other Oligocene passerines described so far from Poland, and that it is younger from the early Oligocene Wieslochia weissi, Jamna szybiaki, Resoviaornis jamrozi and ZPALWr. A/4004 (Bochenski et al., in press) might mean that it represents a different taxon. However, the material available is too scanty to describe it as a new extinct species.

It is generally accepted that the proportions of the nonungual phalanges reflect the locomotor habits of birds. In modern birds with grasping feet, i.e., including many passerines, the penultimate phalanx of digits II, III and IV is typically longer than the more proximal phalanges (e.g., Hopson, 2001; Morschhauser et al., 2009; Stresemann, 19271934). The phalangeal proportions of ZPALWr. A/ 4005 correspond well with those of typical "arboreal" modern birds (Hopson, 2001). Living birds with grasping feet are distinguished in that the penultimate phalanx 3 of digit III is relatively longer than the other phalanges in the digit and, consequently, it constitutes a larger percentage of the total length of the digit (in our case $39.7 \%$ of the three nonungual phalanges). The higher the percent total length of phalanx III-3, the more specialized the foot appears to be for grasping (Morschhauser et al., 2009). Of the 39 passerine species studied by Hopson (2001), the most similar to ZPALWr. A/4005 in phalangeal proportions are two "arboreal" species Catharus fuscescens and Cyanocitta cristata whose penultimate phalanges of digit III make up $38.0 \%$ and $38.6 \%$ of the three nonungual phalanges, respectively, but they have much longer tarsometatarsus than our specimen. The two modern species with the absolute length of the tarsometatarsus similar to ZPALWr. A/4005 also have their phalangeal proportions similar to our fossil specimen - the penultimate phalanx of digit III makes up $41.4 \%$ in Parus major and $37.4 \%$ in Passer montanus (own data). However, the relative proportion of phalanx III-3 should be interpreted with caution because Hopson's (2001) measurements of the "terrestrial" Menura novaehollandiae $(39.2 \%)$ are also similar to that of ZPALWr. A/4005.

Short legs are interpreted as adaptations to arboreal locomotion and indeed many species that forage in trees have their leg bones shorter than those foraging on the ground (e.g., Zeffer et al., 2003). Therefore, the short tarsometatarsus of ZPALWr. A/4005 would support the conclusions drawn from the proportions of phalanges but caution is advised because we do not know what the remaining leg bones looked like. Unfortunately, not much can be drawn from the relatively little curvature of the claws in ZPALWr. A/4005 because it does not preclude ground or arboreal foraging behaviour (Glen and Bennett, 2007).

The evidence discussed above strongly suggests that ZPALWr. A/4005 was an arboreal rather than terrestrial bird. In this respect it differed from the early Oligocene Jamna szybiaki, Resoviaornis jamrozi and ZPALWr. A/4004 (Bochenski et al., 2011, 2013a, in press, respectively) that spent much time on the ground, foraging among trees and shrubs.

\section{ACKNOWLEDGEMENTS}

We thank K. Wertz for his help in editorial works that included the text and figures.

\section{REFERENCES}

Baumel, J.J. and Witmer, L.M. 1993. Osteologia, p. 45132. In Baumel, J.J., King, A.S., Breazile, J.E., Evans, H.E., and Vanden Berge, J.C. (eds.), Handbook of Avian Anatomy: Nomina Anatomica Avium. Nuttall Ornithological Club, Cambridge, Massachusetts.

Berggren, W.A., Kent, D.V., Swisher, C.C., and Aubry, M.P. 1995. A revised Cenozoic geochronology and chronostratigraphy, p. 129-212. In Berggren, W.A., Kent, D.V., Aubry, M.P., and Hardenbol, J. (eds.), Geochronology, Time Scales and Global Stratigraphic Correlation, SEPM Special Publication No. 54. Society for Sedimentary Geology, Tulsa.

Bochenski, Z. and Bochenski, Z.M. 2008. An Old World hummingbird from the Oligocene: a new fossil from Polish Carpathians. Journal of Ornithology, 149:211216. doi:10.1007/s10336-007-0261-y 
Bochenski, Z. and Szymczyk, W. 1979. Szczątki ptaka z Oligocenu Karpat Fliszowych, p. 55. In Kotlarczyk, J. (ed.), Badania Paleontologiczne Karpat Przemyskich (Materiały IV Krajowej Konferencji Paleontologów, Przemyśl, 25-27 czerwca 1979). Wydawnictwo Akademii Górniczo-Hutniczej, Kraków.

Bochenski, Z.M., Tomek, T., and Swidnicka, E. in press. The first complete leg of a passerine bird from the early Oligocene of Poland. Acta Palaeontologica Polonica. http://dx.doi.org/10.4202/app.2012.0021. (Open Access)

Bochenski, Z.M., Tomek, T., and Swidnicka, E. 2010. A columbid-like avian foot from the Oligocene of Poland. Acta Ornithologica, 45:233-236.

Bochenski, Z.M., Tomek, T., and Swidnicka, E. 2013b. A review of avian remains from the Oligocene of the Outer Carpathians and Central Paleogene Basin, p. 37-41. In Göhlich, U.B. and Kroh, A. (eds.), Paleornithological Research 2013 - Proceedings of the 8th International Meeting of the Society of Avian Paleontology and Evolution. Naturhistorisches Museum Wien, Vienna.

Bochenski, Z.M., Tomek, T., Bujoczek, M., and Wertz, K. 2011. A new passerine bird from the early Oligocene of Poland. Journal of Ornithology, 152:1045-1053. doi:10.1007/s10336-011-0693-2. (Open Access)

Bochenski, Z.M., Tomek, T., Wertz, K., and Swidnicka, E. 2013a. The third nearly complete passerine bird from the early Oligocene of Europe. Journal of Ornithology, 154:923-931. doi:10.1007/s10336-013-0958-z. (Open Access)

Boles, W.E. 1995. The world's oldest songbird. Nature, 374:21-22.

Boles, W.E. 1997. Fossil songbirds (Passeriformes) from the Eocene of Australia. Emu, 97:43-50.

Daniltshenko, P.G. 1946. Svetyashschyesya ryby semeystva Gonostomatidae iz tretitshnykh otlozheniy Kavkaza i Kryma. Izvestiya Akademii Nauk SSSR, Seria biologicheskaya, 6:639-646. (In Russian)

Daniltshenko, P.G. 1947. Ryby semeystva Myctophidae iz kavkazkogo oligotsena. Doklady AN SSSR, 56:193-196. (In Russian)

Glen, C.L. and Bennett, M.B. 2007. Foraging modes of Mesozoic birds and non-avian theropods. Current Biology, 17:R911-R912.

Heckel, J.J. 1850. Beiträge zur Kenntnis der fossilen Fische Osterreiches. Denkschriften der Kaiserlischen Akademie der Wissenschaften Mathematisch-Naturwissenschaftliche Classe, 1:201-242.

Hopson, J.A. 2001. Ecomorphology of avian and nonavian theropod phalangeal proportions: implications for the arboreal versus terrestrial origin of bird flight, p. 211-235. In Gauthier, J. and Gall, L.F. (eds.), New Perspectives on the Origin and Evolution of Birds (Proceedings of the International Symposium in honor of John H. Ostrom). Peabody Museum of Natural History, Yale University.
Kotlarczyk, J., Jerzmańska, A., Świdnicka, E., and Wiszniowska, T. 2006. A framework of ichthyofaunal ecostratigraphy of the Oligocene-Early Miocene strata of the Polish Outer Carpathian basin. Annales Societatis Geologorum Poloniae, 76:1-111.

Linck, H.F. 1790. Versuch einer Eintheilung der Fische nach den Zähnen. Magazin für das Neueste aus der Physik und Naturgeschichte, 6(3):28-38.

Linnaeus, C. 1758. Systema naturae per regna tria naturae: secundum classes, ordines, genera, species, cum characteribus, differentiis, synonymis, locis (10th edition). Laurentius Salvius, Stockholm.

Manegold, A. 2008. Passerine diversity in the late Oligocene of Germany: earliest evidence for the sympatric coexistence of Suboscines and Oscines. Ibis, 150:377-387.

Manegold, A., Mayr, G., and Mourer-Chauviré, C. 2004. Miocene songbirds and the composition of the European passeriform avifauna. Auk, 121:1155-1160.

Mayr, G. 2009. Paleogene Fossil Birds. Springer, Berlin.

Mayr, G. and Manegold, A. 2004. The oldest European fossil songbird from the early Oligocene of Germany. Naturwissenschaften, 91:173-177.

Mayr, G. and Manegold, A. 2006a. New specimens of the earliest European passeriform bird. Acta Palaeontologica Polonica, 51:315-323.

Mayr, G. and Manegold, A. 2006b. A small suboscinelike passeriform bird from the early Oligocene of France. Condor, 108:717-720.

Morschhauser, E.M., Varricchio, D.J., Chunling, G., Jinyuan, L., Xuri, W., Xiadong, C., and Qingjin, M. 2009. Anatomy of the early Cretaceous bird Rapaxavis pani, a new species from Liaoning Province, China. Journal of Vertebrate Paleontology, 29:545554.

Mourer-Chauviré, C. 2006. The avifauna of the Eocene and Oligocene phosphorites du Quercy (France): an updated list. Strata, série 1, 13:135-149.

Mourer-Chauviré, C., Berthet, D., and Hugueny, M. 2004. The late Oligocene birds of the Créchy quarry (Allier, France), with a description of two new genera (Aves: Pelecaniformes: Phalacrocoracidae, and Anseriformes: Anseranatidae). Senckenbergiana lethaea, 84:303-315.

Mourer-Chauviré, C., Hugeney, H., and Jonet, P. 1989. Découverte de Passeriformes dans l'Oligocène supérieur de France. Comptes Rendus de l'Académie des Sciences de Paris, Série II, 309:843849.

Stresemann, E. 1927-1934. Aves, p. 1-899. In Kükenthal, W. and Krumbach, T. (eds.), Handbuch der Zoologie. Walter de Gruyter, Berlin.

Zeffer, A., Johansson, L.C., and Marmebro, A.. 2003. Functional correlation between habitat use and leg morphology in birds (Aves). Biological Journal of the Linnean Society, 79:461-484. 